\title{
DNase I levels and disease outcome in JIA patients treated with etanercept
}

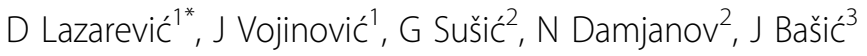 \\ From 18th Pediatric Rheumatology European Society (PReS) Congress \\ Bruges, Belgium. 14-18 September 2011
}

\section{Background}

Failure to efficiently degrade the DNA of apoptotic cells activates innate immunity, by induction of TNFó and IFN $\beta$ production, causing chronic arthritis. If deficient, DNase I could leed to accumulation of undigested DNA which induce activation of phagocytes and production of proinflammatory cytokines, notably TNF.

\section{Aim}

Disease outcome in JIA patients after one year of treatment with TNFó therapy and their DNase I levels.

\section{Methods}

The study was performed in 25 JIA patients who donated paired serum samples prior and one year after continous etanercept therapy. Basic clinical data (six core set variables defined in ACR PEDI outcome score) were recorded along with alkalyne DNase I serum levels using the method where acid soluble nucleotides are determined spectrophotometrically at $260 \mathrm{~nm}$. Treatment schedule of etanercept was $0,4 \mathrm{mg} / \mathrm{kg}$ body weight subcutaneously twice weekly.

\section{Results}

JIA patients mean age was $14,7+/-4,22$ and disease duration is $6,59+/-2,76$. Disease type distribution was $8 \%$ systemic, $28 \%$ polyarticular RF-, $25 \%$ polyarticular RF+, $17 \%$ ERA and $21 \%$ extended oligoarticular JIA. Summary of data results prior and after anti TNFó therapy: ESR $26,88$ vs. 15,52 ( $\mathrm{p}<0,01)$; patientVAS 40,24 vs. 24,40 $(\mathrm{p}<0,05)$; physicianVAS 38,08 vs.10,32 $(\mathrm{p}<0,01)$; CHAQ $0,674$ vs.0,375 ( $\mathrm{p}<0,01)$; LOM 15,52 vs. 11,68 (NS); AA 9,24 vs.2,64 $(\mathrm{p}<0,01)$. DNase I levels were significantly lower prior $(2.934 \mathrm{U} / \mathrm{l})$ compared to values after one

\footnotetext{
* Correspondence: lazarevic.gaga@gmail.com

${ }^{1}$ Department of Pediatric Rheumatology, University Clinical Center Niš, Serbia Full list of author information is available at the end of the article
}

year therapy $(4,184 \mathrm{U} / \mathrm{l} ; \mathrm{p}<0,01)$. We have found correlation between DNase I levels and AA $(r=-0,993 \mathrm{p}<0,5)$ and other clinical outcome variables prior and after therapy.

\section{Conclusion}

JIA patients with active disease have decreased DNase I levels. Our results indicate significant increase of DNase I in the sera of JIA patients after one year of anti TNFó therapy which was associated to the disease clinical improvement.

\section{Author details}

${ }^{1}$ Department of Pediatric Rheumatology, University Clinical Center Niš, Serbia. ${ }^{2}$ Institute of Rheumatology, Belgrade, Serbia. ${ }^{3}$ Department of Biochemistry, Faculty of Medicine, Niš, Serbia.

Published: 14 September 2011

doi:10.1186/1546-0096-9-S1-P171

Cite this article as: Lazarević et al:: DNase I levels and disease outcome

in JIA patients treated with etanercept. Pediatric Rheumatology 20119 (Suppl 1):P171.

Submit your next manuscript to BioMed Central and take full advantage of:

- Convenient online submission

- Thorough peer review

- No space constraints or color figure charges

- Immediate publication on acceptance

- Inclusion in PubMed, CAS, Scopus and Google Scholar

- Research which is freely available for redistribution

Submit your manuscript at www.biomedcentral.com/submit

\section{() Biomed Central}

C Biomed Central

(c) 2011 Lazarevićć et al; licensee BioMed Central Ltd. This is an open access article distributed under the terms of the Creative Commons Attribution License (http://creativecommons.org/licenses/by/2.0), which permits unrestricted use, distribution, and reproduction in any medium, provided the original work is properly cited. 